\section{Kortfattet og oppdatert om depotbehandling}

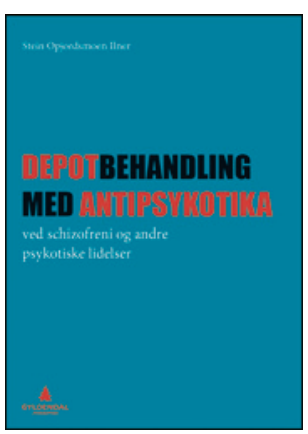

Stein Opjordsmoen Ilner

Depotbehandling med antipsykotika

Ved schizofreni og andre psykotiske lidelser.

102 s, tab, ill. Oslo: Gyldendal Akademisk,

2014. Pris NOK 245

ISBN 978-82-05-46874-0

Forfatteren er spesialist i psykiatri og nevrologi, har bred klinisk erfaring og er en nestor i norsk psykoseforskning. Depotbehandling med antipsykotika gir en oppdatert oversikt fortrinnsvis over medikamentell behandling ved psykoselidelser, men også med et blikk på integrert og ikke-medikamentell behandling. Ettersom boken kan referere til den nye nasjonale faglige retningslinjen for behandling av personer med psykoselidelser, kan forfatteren begrense seg til å gi en kortfattet, oppdatert introduksjon til psykosesykdommene, utredning, klassifikasjon og ikke-medikamentell behandling av disse.

Han har da mulighet til å gå mer i detalj vedrørende medisinering, spesielt depotbehandling. Den delen av boken som omhandler farmakoterapi, er minst like omfattende som den delen som gjelder depotmedisinering, dog ikke på samme detaljeringsnivå. Her presenteres en balansert fremstilling av en forfatter som har svært god oversikt over psykosefeltet. Han evner å gi en effektiv, men helhetlig, fremstilling som integrerer forskning og klinisk praksis. Historikk, nevrobiologiske hypoteser, bivirkninger og kunnskaper for bedret etterlevelse er noen av temaene som blir gjennomgått.

Timingen på utgivelsen er god i det man de siste årene har fått tilgang til flere andregenerasjonsantipsykotika i depotform, etter mange år med kun førstegenerasjonsmidler som depotinjeksjon. Kunnskapsbasen innen depotmedisinering øker raskt, og her finnes en god innføring og oversikt over denne litteraturen.

Omslagsdesignen er like elegant som på forfatterens utgivelse fra 2012, Akuttpsykiatri. Det er ingen illustrasjoner eller figurer, men avslutningsvis finner man to oversiktlige tabeller med depotpreparater som markedsføres i Norge, og sammenlikninger av viktige og praktiske karakteristika ved disse. Tross mangel på illustrasjoner fremstår ikke boken tunglest ettersom format og layout gir et luftig uttrykk.

Alle fagpersoner som møter voksne pasienter med psykoselidelser, vil kunne ha stor nytte av denne boken. Kapitlet om depotbehandling er kanskje mest aktuelt for ansatte i spesialisthelsetjenesten, men kan også være relevant for interesserte allmennpraktikere og helsearbeidere som arbeider med psykose i kommunehelsetjenesten.

\section{Dramatisk familiehistorie fylt av store triumfer og smertelige nederlag}
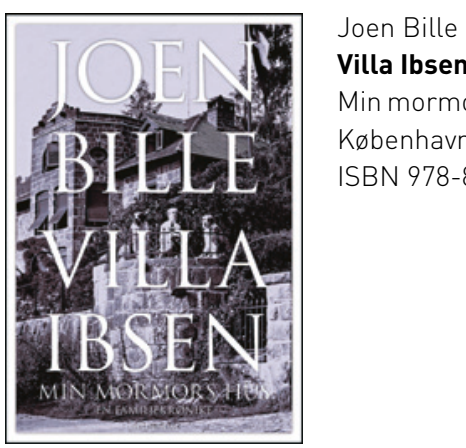

Joen Bille

Villa Ibsen

Min mormors hus. En familiekrønike. 328 s, ill. København: Gyldendal, 2014. Pris DKK 300 ISBN 978-87-02-15903-5

Villa Ibsen - Min mormors hus er en velskrevet og velkomponeret fremstilling af Henrik Ibsen og Bjørnstjerne Bjørnsons, den danske skuespiller Joen Billes oldefædres ved giftermål sammenknyttede familier og deres temperamentsfyldte efterkommeres krønike med detaljer genfortalt i familien gennem fire generationer. Her hører vi om hvordan Ibsens forfatterskab til dels udsprang af slægtsbegivenheder og blev afpudset under oplæsning hjemme af hustruen Suzannah og af sønnen Sigurd Ibsen, den senere statsminister ved unionsopløsningen og morfar til Bille.

Der er omtale af de berømte slægtninges sygdom og død. Bjørnson var i 1909 blevet ramt af et slagtilfælde. For at opnå den bedste behandling fik man ham transporteret til Paris i en kongelig salonvogn. Intet hjalp. Dødskampen trak ud. I månedsvis var familien samlet omkring ham på et hotel før han sov ind.

Et hovedtema er «Villa Ibsen» i Norditalien. Den var indrettet og beboet af Sigurd Ibsen og hustru Bergliot, f. Bjørnson og et samlingspunkt for familien under lange ferier. Mormors hus rummede mange møbler fra oldeforældrene i Oslo men blev solgt i 1968 sammen med Villa Ibsen, da de hjemlige myndigheder ikke var interesseret. En ring sluttedes i samspillet mellem forfatterskab, samfund og familie, da forfatterhjemmet i lejligheden nær Slottet i Oslo kunne genskabes som Ibsenmuseet med inventar i $2002 \mathrm{købt}$ tilbage af den norske stat fra de italienske ejere under Joen Billes medvirken.

Bogen har almen interesse for norske læsere.

En bemærkning om at Tancred Ibsen sammen med sine norske officerskolleger var i tysk koncentrationslejr under 2 . verdenskrig bør nok rettes til at onkelen, slemt nok endda, sad i tysk krigsfangelejr.

Troels Kardel

Pensioneret læge dr.med Holte, Danmark 